\title{
Mídia, Ciência e Ensino: análise de materiais desenvolvidos por licenciandos em Física ${ }^{+*}$
}

\author{
Danilo Cardoso ${ }^{1}$ \\ Instituto Federal de São Paulo \\ São Paulo - SP
}

\section{Resumo}

Este trabalho analisa materiais desenvolvidos por licenciandos em fisica. $O$ material analisado compreende análises, feitas pelos licenciandos, de materiais de mídia por eles selecionados e planos de aulas de física que desenvolveram, envolvendo o uso desses materiais selecionados e analisados. O material foi categorizado em três eixos interdependentes: mídia, ciência e ensino e foi analisado a partir da metodologia da análise textual discursiva e com base em fundamentação teórica pautada na epistemologia freireana. Nossa análise mostrou, dentre outros resultados, que os licenciandos desenvolveram análises críticas de materiais da mídia e propuseram planos de aula de física com abordagens contextualizadas da ciência. Contudo, a análise também demonstrou obstáculos à proposição de atividades que buscassem uma apropriação crítica e propositiva da mídia em aulas de física. Estes obstáculos são interpretados como fruto de tensões entre a busca por implementar novas perspectivas educacionais e as condições concretas nas quais estão inseridos os licenciandos. Por fim, defende-se que o enfrentamento das questões relacionadas à mídia no contexto de pósverdade não deve se dar pelo controle do que deve ou não ser publicado, mas sim por uma educação comprometida com a problematização da mídia, que busque proporcionar condições para que cidadãs e cidadãos lidem de maneira crítica com a mídia.

Palavras-chave: Midia; Ciência; Formação de Professores.

\footnotetext{
${ }^{+}$Media, Science and Education: analysis of materials developed by physics teachers in initial training

* Recebido: junho de 2020. Aceito: outubro de 2020.

${ }^{1}$ E-mail: danilo.cardoso.fis@gmail.com
} 


\begin{abstract}
This work analyzes materials developed by physics teachers in initial training. The analyzed material comprises analyzes, made by the undergraduates, of media materials selected by them and plans of physics classes that they developed, involving the use of these selected and analyzed materials. The material was categorized into three interdependent axes: media, science and teaching and was analyzed using the discursive textual analysis methodology and based on theoretical foundations based on Freire's epistemology. Our analysis showed, among other results, that the undergraduate students developed critical analyzes of media materials and proposed physics lesson plans with contextualized approaches to science. However, the results also demonstrate obstacles to the proposition of activities that seek a critical and purposeful appropriation of the media in physics classes. These obstacles are interpreted as the result of tensions between the search to implement new educational perspectives and the concrete conditions in which the undergraduate students are inserted. Finally, it is argued that the confrontation of issues related to the media in the post-truth context should not take place through the control of what should or should not be published, but through an education committed to the problematization of the media, which seeks to provide conditions for citizens to deal critically with the media.
\end{abstract}

Keywords: Media; Science; Teatcher Training.

\title{
I. Introdução
}

Há décadas pesquisadores em ensino de ciências apresentam defesas por uma educação científica compromissada com o desenvolvimento de dimensões presumidas como importantes para cidadãos contemporâneos, atuantes nas sociedades de seu tempo. Para isto, é premente identificarmos e debatermos as questões pujantes em nossa sociedade contemporânea para pensarmos a educação científica. São vários os temas que poderiam ser colocados em pauta, tais como desigualdade social e econômica e seus desdobramentos no acesso à ciência e aos seus produtos, modelos de consumo e de exploração de recursos naturais, desequilíbrio ambiental, representatividade étnica e de gênero na ciência, ascensão de movimentos anticientíficos, entre outros.

Em meio a essas e outras questões, podemos identificar como uma marca de nossa sociedade atual o dinamismo no acesso e na disseminação de informações. Em outras palavras, vivemos em um mundo midiático, em uma sociedade considerada como sociedade 
da informação, "caracterizada por criar e utilizar constantemente novas tecnologias de informação e comunicação (TICs) e definir suas relações sociais e econômicas em torno do seu objeto informação" (LEITE; MATOS, 2017, p. 2335). Assim, na sociedade contemporânea a manutenção do status quo e a disputa pelo poder também assumem uma dimensão informacional (idem).

Neste contexto, temos presenciado recentemente o surgimento e popularização de termos como fakenews, pós-verdade e desinformação. Tais termos veem atrelados, em geral, à preocupação com a veracidade e a confiabilidade das informações disseminadas na web, que formam opiniões e constroem pretensos conhecimentos, baseados em informações falsas ou imprecisas. (LEITE; MATOS, 2017, p. 2335).

Os termos fakenews e pós-verdade ganharam notoriedade no final do ano de 2016. De acordo com Genesini (2018, p. 47), esses termos foram criados, principalmente, para dar sentido a dois fenômenos que surpreenderam a opinião pública no ano referido, a saber, o movimento que ficou conhecido como Brexit ${ }^{2}$ e a eleição de Donald Trump para a presidência dos Estados Unidos da América.

Assim, no ano de 2016 o dicionário de Oxford definiu "pós-verdade" como a palavra do ano, justificando que o uso deste termo havia crescido enormemente, principalmente associado aos dois eventos destacados por Genesini.

O dicionário de Oxford enunciou o significado do termo pós-verdade da seguinte maneira: "um adjetivo relacionado ou evidenciado por circunstâncias em que fatos objetivos têm menos poder de influência na formação da opinião pública do que apelos por emoções ou crenças pessoais". (Oxford dictionaries apud GENESINI, 2018, p. 47). Desta maneira, pósverdade é um conceito social de longo alcance que ameaça os conceitos tradicionais de conhecimento, tomada de decisão e política (JANDRIÉ, 2018). Nesta nova relação com o conhecimento ocorre a "ascensão da desconfiança em relação à história oficial, e a sobrecarga cognitiva com o excesso de informação leva a uma condição de apatia denominada por alguns autores de 'zumbificação da informação' em que as pessoas consomem e disseminam informações falsas ou distorcidas sem notar". (COSTA et al., 2020, p. 223). Por exemplo, em trabalho recentemente publicado na prestigiada revista Science, conclui-se que informações falsas no Twitter são tipicamente retuitadas por muito mais pessoas, e muito mais rápido, se comparada a informações verdadeiras, especialmente quando o tópico é política (LAZER et al., 2018).

Para Silvio Genesini (2018), contudo, não há nenhuma novidade na tentativa de falsificação política através da distorção de fatos e informações. Para ele, o novo é que estamos em uma nova era, turbinada pela internet e pelas redes sociais, em que o crescimento é viral e o efeito, exponencialmente explosivo: "o novo é o Facebook, o Google e o Twitter, não a tentativa de contar mentiras ou falsificar informações, o que sempre existiu na história do mundo" (GENESINI, 2018, p. 49)

\footnotetext{
${ }^{2}$ Termo cunhado para fazer referência à saída do Reino Unido (Britain e Exit) da União Européia.
} 
Considerando a amplitude e complexidade das discussões acerca desta temática envolvendo pós-verdade e fakenews, poder-se-ia concluir, de maneira apressada, que tais discussões nada ou pouco têm a ver com a educação científica. Contudo, defendemos exatamente o contrário. A inserção do debate sobre esses temas, e a aproximação com perspectivas da educação para as mídias em geral, é fundamental para o ensino de ciências (CARDOSO; GURGEL, 2019).

Uma forma de associarmos o contexto da pós-verdade ao contexto de interesse da ciência, e de seu ensino, é reconhecer a ascensão de movimentos anticientíficos que ganham força, principalmente, através da mídia. Por exemplo, mesmo a ciência revelando a fraude e a falta de evidências para correlacionar autismo e a vacinação, foi notória a redução da procura pela vacinação em algumas partes do mundo pelo medo do desenvolvimento do autismo e de efeitos adversos graves associados aos componentes presentes nas formulações das vacinas, dando força ao movimento antivacina (COSTA et al., 2020).

Considerando este contexto, temos o desafio de problematizar a mídia na educação científica, sobretudo visando a formação básica dos cidadãos e cidadãs. Mariana Pezzo (2016) afirma que embora a escola e os diferentes integrantes da comunidade escolar estejam inseridos em relações cotidianas com a mídia e com tecnologias de informação e comunicação (TICs), ainda não há no Brasil, e em muitos outros países, "estratégias e políticas de abordagem da mídia e de suas tecnologias em suas interfaces com processos de ensinoaprendizagem e o ambiente escolar" (PEZZO, 2016, p. 19). A autora parte da convicção de que a abordagem das interfaces entre a produção midiática e o ensino de ciências é indispensável, especialmente para um ensino comprometido com a problematização das relações entre Ciência, Tecnologia e Sociedade (CTS).

A literatura que busca aproximações entre as áreas de comunicação e educação, que chamaremos de educação para as mídias, indica que um dos principais obstáculos desta área está relacionado à pouca atenção dada para a formação, inicial e continuada, de profissionais da educação (BÉVORT; BELLONI, 2009). Há um déficit, particularmente, de formação para a mídia nas licenciaturas (PEZZO, 2016). Tendo estes apontamentos em vista, o objetivo geral do presente trabalho será o de apresentar uma análise sobre como um grupo de professores de física em formação inicial avaliou materiais de mídia e propôs sua inserção no ensino de física, a partir da proposição de planos de aulas. O corpus e o contexto da pesquisa serão descritos em detalhes na seção III.

Assim, as principais questões que guiarão a análise e reflexão deste trabalho são: Quais características da mídia são evidenciadas por professores de física em formação em suas análises de materiais midiáticos? Como avaliam a imagem da ciência veiculada pela mídia? Quais são as principais tensões que os licenciandos enfrentam ao buscar aproximações entre mídia e o ensino de física?

Na próxima seção discutiremos alguns fundamentos epistemológicos relacionados à problematização da mídia. Tais fundamentos serão pautados, sobretudo, em concepções 
freireanas de comunicação, diálogo e mídia.

\section{Comunicação e diálogo: fundamentando as discussões sobre a mídia a partir da epistemologia freireana}

A atuação crítica no contexto de um mundo marcado pela pós-verdade passa por problematizar as mensagens que a mídia nos impõe como narrativas hegemônicas sobre a realidade a que estamos submetidos. Além da necessidade de posicionamento crítico a essas produções, é necessário que nos percebamos, educadores e educandos, cidadãos e cidadãs, como tendo potencialidades criativas, propositivas.

Em concordância com sua visão de alfabetização, Paulo Freire entendia que a mídia poderia assumir um papel importante na educação a partir do momento em que os sujeitos fossem estimulados a superar a leitura ingênua de textos, sons e imagens e passassem a fazer uma leitura crítica dos meios de comunicação, que passa por compreender os traços ideológicos da mídia, compreender seu contexto de produção.

Entendendo que um dos problemas centrais envolvendo a mídia é a questão do poder, e o risco que a sociedade civil inteira corre de "ficar manipulada pelos interesses de quem detém o poder sobre esses meios de comunicação" (FREIRE; GUIMARÃES, 2011, p.33), Freire defende que educadores e educadoras "não podem, de maneira nenhuma, no mundo de hoje, silenciar ou botar entre parêntese esse problema" (idem).

Como educadores, temos de saber o que fazer para minimizar esse poder exacerbado nas mãos de um grupo antipopular, para aumentar a capacidade crítica das grandes massas populares, sobre quem recai o peso dos comunicados. Na verdade, o que se está fazendo, em grande parte, com os meios de comunicação, é comunicado! Em lugar de haver comunicação real, o que está havendo é transferência de dados, que são ideológicos e que partem muito bem vestidos. (FREIRE; GUIMARÃES, 2011, p.33)

Claramente não podemos descontextualizar a fala de Freire. Já se passaram mais de três décadas desde o período em que ele e Guimarães, a partir de seus diálogos, propuseram essas reflexões. De lá para cá, tivemos o advento da internet, o surgimento de mídias sociais e mídias alternativas, que tendem a disputar as narrativas sobre os acontecimentos do mundo com os grandes conglomerados que exercem poder sobre e através da mídia. Contudo, especialmente quando tratamos da televisão e rádio, alvo principal das reflexões de Freire e Guimarães, e que são as mídias mais consumidas pelos brasileiros ainda hoje (BRASIL, 2016), consideramos que as afirmações de Freire são atuais. Além disso, também julgamos atual a consideração de que os meios de comunicação priorizam a transferência de dados e que são, necessariamente, ideológicos.

Um dos pontos centrais da teoria de conhecimento de Paulo Freire é o entendimento de que na comunicação e na educação, assim como em qualquer atividade humana, é 
impossível ser neutro. Daí sua defesa de que educação é ato político. Em diálogo inserido em edições recentes do livro "Educar com a mídia", Mariana Faraco questiona Sérgio Guimarães sobre como Paulo Freire veria a questão da neutralidade na prática jornalística considerando, segundo ela, que "o ideal do jornalismo, para nós que estudamos, é recontar a realidade da maneira mais fiel possível, o que não significaria necessariamente uma neutralidade." (FREIRE; GUIMARÃES, 2011, p.150). Ao reponde-la, Guimarães chama a atenção para a prática do jornalista como uma prática profissional, dando destaque ao texto de Freire " $O$ compromisso do Profissional com a Sociedade":

No fundo, a chamada neutralidade nada mais é do que a manifestação ideológica de um compromisso enrustido, ou seja: um órgão de comunicação que não quer manifestar claramente seu compromisso, que não quer reconhecer que tem um compromisso com determinado grupo ou com ele próprio, costuma sustentar a ideologia da neutralidade (FREIRE; GUIMARÃES, 2011, p. 152).

Julgamos que o entendimento de que não há possibilidade de produção neutra seja um ponto central das contribuições de Freire para a aproximação que buscamos entre educação científica e mídia. É preciso enfatizar que as narrativas sobre o mundo, e sobre a ciência em particular, estão impregnadas por diversas visões de mundo. Assim, o que deve haver de mais básico na aproximação da educação com a mídia, além de perceber seus traços ideológicos, é a busca por identificar diferentes visões, conflitantes ou não, sobre um mesmo fato.

Assim, tomando a teoria do conhecimento de Freire para problematizar a mídia na educação, e particularmente na educação científica, é fundamental que se considere que os sujeitos estão implicados na construção e reconstrução das interpretações sobre o mundo, com o mundo. Considerar que "Comunicação [é] a co-participação dos Sujeitos no ato de pensar (...) [a comunicação] implica uma reciprocidade que não pode ser rompida (...) comunicação é diálogo na medida em que não é transferência de saber, mas um encontro de Sujeitos interlocutores que buscam a significação dos significados" (FREIRE, 1971 apud MEDITSCH; FARACO, 2003, p. 3). Com isto, percebe-se a relação imbricada entre comunicação e diálogo. Reconhecidamente, o diálogo tem papel de destaque na epistemologia freireana. Para ele, não há construção ou apreensão de conhecimento sem diálogo: "Somente o diálogo, que implica num pensar crítico, é capaz, também, de gerá-lo. Sem ele, não há comunicação e sem esta, não há verdadeira educação [...] A educação autêntica não se faz de A para B ou de A sobre B, mas de A com B, mediatizados pelo mundo" (FREIRE, 1970 apud MEDITSCH; FARACO, 2003, p. 3).

Assim, para aproximarmos as questões sobre mídia, e particularmente a mídia sobre ciência, e a educação científica, é imprescindível que a educação para e pelas mídias seja desenvolvida a partir de uma visão problematizadora e não bancária, que busque analisar as diferentes abordagens dadas a um mesmo tema. Ou seja, é fundamental, senão básico, confrontar diversas visões de mundo que circulam na mídia. A compreensão de que existem 
diversas possibilidades de abordar um mesmo tema é condição primordial para que possamos construir nossas próprias visões de mundo. Ana Maria Freire, companheira de Paulo Freire nas décadas de oitenta e noventa, diz em entrevista à Mariana Faraco (2003), que Freire comparava os telejornais entre si para ver o modo com as notícias eram tratadas:

\begin{abstract}
"Nós assistíamos diariamente aos telejornais, poderia ser tanto o do Bóris Casoy como o Jornal Nacional. Esporadicamente, assistíamos aos dois e, às vezes, também ao jornal da Cultura, para que Paulo pudesse analisar e procurar mais fidelidade ao fato que estava sendo narrado, para ver as deformações pelos interesses ideológicos e políticos que as emissoras transmitem.(...) Muitas vezes, ele chegava até a se irritar pela forma às vezes superficial e omissa de [ o Jornal Nacional] dizer de fato a coisa, manipulando trechos de entrevista que tínhamos visto em outra emissora, induzindo a opinião pública a perpetuar a sociedade vigente. Foi contra essa sociedade que Paulo esteve sempre contra, e por isso pagou com quase 16 anos de exílio." (ANA MARIA ARAÚJO FREIRE, entrevista em 08/04/2002 apud MEDITSCHI; FARACO, 2003).
\end{abstract}

A declaração de Ana Maria Freire mostra como o sentido da comunicação não se dá de forma unilateral. Isto é, a interação entre emissor-receptor deve ser considerada na comunicação social. De acordo com a pedagogia freireana, podemos afirmar que o conhecimento, ou informação, não se dá de alguém que detém o conhecimento para àqueles que, equivocadamente, são considerados tabulas rasas. Ao contrário, essa relação gnosiológica se dá na interação entre as pessoas, mediadas pelo mundo. Ser capaz de criticar as narrativas da mídia passa por reconhecer, como defendia Paulo Freire, que a produção midiática não é boa e nem má em si mesma, mas que potencialmente serve a interesses. Assim, questionar a serviço "do quê" e a serviço "de quem" as mídias estão, implica questionar sobre o poder exercido pela e através da mídia.

Para problematizar a mídia também é fundamental que se reconheça os recursos de linguagem empreendidos para que as narrativas sejam construídas. Por exemplo, é comum em materiais midiáticos sobre ciência que se use metáforas como recurso linguístico. Os usos da linguagem na mídia podem ter vários vieses, como capturar nossa atenção, provocar nossas emoções, persuadir-nos a determinadas compreensões e pontos de vista etc. Além disso, existe o desafio de passar de uma linguagem específica e complexa como a da Ciência, para uma linguagem destinada a um público de não especialistas. Essa tentativa de passar de uma linguagem à outra, em um processo de reinterpretação, pode implicar em um processo de simplificação. O problema central da simplificação é que ela pode comprometer a precisão das teorias e conceitos científicos construídos a partir da linguagem da Ciência.

Ainda em relação à dinâmica de produção da mídia, é importante percebermos a utilização de sensacionalismos e frases de efeito. A jornalista Mônica Teixeira (2002) afirma categoricamente que o jornalismo sobre ciência é sensacionalista, ponderando que "o acontecimento que não causa espanto, uma sensação, não preenche os requisitos da notícia” 
(TEIXEIRA, 2002, p. 140). Contudo, a busca por causar sensações pode resultar em uma extrapolação da realidade e produzir um verdadeiro espetáculo sobre os fatos. Do ponto de vista pedagógico, no entanto, as produções sensacionalistas podem proporcionar a problematização de um dado tema científico e fomentar a discussão sobre os processos de produção da mídia (RIBEIRO; KAWAMURA, 2008, p.7).

A aproximação entre a educação para as mídias e o ensino de ciências deve considerar que as mídias são responsáveis por um processo de transmissão, negociação e apropriação de saberes que podem contribuir para manter ou transformar grupos e sociedades. Esse olhar representa um entendimento sobre as mídias e seu lugar na sociedade e na formação dos indivíduos, que deve ir além de usos instrumentais de materiais da mídia. Assim, devemos considerar os materiais midiáticos "não apenas como instrumentos a serem manejados corretamente e que, para isso, requerem um aprendizado. Não apenas como meios que, utilizados, promovem uma leitura diferenciada do processo de produção midiática. Mas como processos que determinam - em diálogo ou tensão com outras instituições socializadoras - a forma como se constrói o pensamento e o conhecimento hoje e a forma com que os indivíduos se relacionam entre eles e com o mundo" (PRAZERES, 2009, p. 7).

A aproximação entre a educação para as mídias e o ensino de ciências deve buscar, além de reflexões críticas e analíticas sobre os meios de comunicação e as possibilidades de atuação crítica e criativa através das mídias, a problematização do próprio conhecimento científico e de suas relações com o desenvolvimento tecnológico e com a organização social de maneira mais ampla. Entendemos ser fundamental na problematização da ciência veiculada na mídia a discussão de características epistemológicas do conhecimento científico, de modo que sejam superadas visões estereotipadas da ciência, tais como a "mitologia dos resultados" que representa o fazer científico apenas por seus produtos, "ignorando os processos (históricos, sociais e culturais) e os procedimentos (metodológicos) inerentes à atividade científica; na compreensão dos resultados das pesquisas como decorrentes de procedimentos cumulativos e finalistas [...]" (RIBEIRO; KAWAMURA, 2008, p. 4), a crença em um método científico único e universal, o "mito do gênio" que identifica apenas grandes nomes como Einstein, Newton, Galileu etc, como responsáveis pela construção de conhecimento científico, dentre outras.

Além de um aprofundamento de aspectos epistemológicos relacionados à dinâmica de produção e funcionamento da ciência, a aproximação entre as perspectivas da educação para as mídias e o ensino de ciências deve problematizar os desdobramentos tecnológicos, sociais e ambientais implicados nas temáticas científicas abordadas pela mídia.

Como indicamos na introdução deste trabalho, a formação de professores é condição sine qua non na busca por inserir perspectivas da educação para as mídias no ensino de ciências. Assim, além da dimensão midiática e da própria ciência, temos que negociar as tensões geradas por essa aproximação nas práticas de ensino. Em outras palavras, é indispensável que a busca pela problematização da mídia e da ciência em aulas de física se dê 
a partir de práticas de ensino que valorizem o diálogo como fundamento das atividades propostas e que busquem o desenvolvimento de possibilidades de participação criativa, e não passiva, dos alunos. Um dos desafios, portanto, é negociar as tensões e conflitos gerados entre novas perspectivas educacionais, como as discutidas neste trabalho, e as condições concretas e materiais em que estão inseridos os professores em formação.

Assim, nossa análise dos materiais desenvolvidos pelos licenciandos será pautada em três eixos interdependentes que serão apresentados na próxima seção: Mídia, Ciência e Ensino.

A seguir apresentamos o contexto no qual desenvolvemos práticas de ensino que buscaram a aproximação de perspectivas da educação para as mídias e do ensino de ciências na formação de futuros professores de física. Apresentamos, também, a metodologia da análise textual discursiva, que embasou nossa análise dos materiais produzidos pelos licenciandos.

\section{Campo, corpus e referencial metodológico}

\section{III.1 Campo}

Para a consecução dos objetivos apresentados neste trabalho, a investigação foi realizada no contexto de uma disciplina do curso de licenciatura em Física do Instituto Federal de Educação, Ciência e Tecnologia de São Paulo (IFSP). Ministrada no primeiro semestre de 2018, a disciplina Introdução ao Ensino e Divulgação da Ciência (EDCZ2) é obrigatória e destinada a alunos do segundo semestre da licenciatura em Física, com cinco aulas semanais de 45 min cada.

A disciplina versou sobre questões variadas da divulgação científica e do ensino de ciências. Portanto, os trabalhos analisados neste artigo são fruto de uma sequência de aulas desta disciplina, na qual se abordou temas da educação para a mídia e possíveis perspectivas de aproximação com o ensino de ciências. Além desta sequência de aulas, em outro momento da disciplina os alunos empreenderam análises de uma reportagem publicada pela VEJA sobre a descoberta do bóson de Higgs, focados na discussão sobre aspectos da Natureza da Ciência.

O conjunto de aulas que resultou nos trabalhos desenvolvidos pelos licenciandos e analisados neste artigo começou com a proposição de dois encontros, totalizando cinco aulas expositivo-dialógicas, sobre fundamentos da "educação para as mídias". Sugeriu-se que os alunos lessem o texto "Mídia, Escola e Leitura Crítica do Mundo" (CALDAS, 2006). Durante as aulas, foram apresentadas partes da fundamentação freireana para a abordagem da mídia, presente na seção II deste trabalho. Por último, apresentaram-se algumas características mais específicas do jornalismo científico, pautadas, sobretudo, no artigo de Bertolli (2006).

Em seguida, foi proposta uma aula usando materiais de mídia. À guisa do timing das observações do eclipse solar que corroborou a teoria da relatividade geral, prestes a completar 
seu centenário, foram selecionados textos midiáticos publicados no contexto das expedições inglesas que corroboraram a teoria de Einstein em 1919. Os alunos leram dois artigos do jornal Times London e um do New York Times, traduzidos pelo Professor. O foco da aula foi o de explorar o importante papel da mídia em ascender a imagem de Einstein ao mundo e discutir o contexto social e político no qual as expedições foram empreendidas.

Após esse conjunto de aulas, propôs-se que os licenciandos, em grupos, preparassem planos de aulas de física nas quais inserissem materiais de mídia. Tanto os temas quanto o tipo de material midiático a ser selecionado foram de livre escolha dos grupos. A única exigência foi a de que selecionassem, no mínimo, dois materiais diferentes para o mesmo tema. Os licenciandos apresentaram suas análises e propostas de aulas em seminários, que foram gravados com prévio consentimento. Além dos seminários, os licenciandos entregaram versões escritas de seus trabalhos, nos quais constam as análises dos materiais midiáticos selecionados pelos grupos e os planos de aulas propostos a partir dessas análises. Tanto os vídeos quanto os textos compõem o corpus deste trabalho.

\section{III.2 Corpus}

O corpus da pesquisa apresentada neste trabalho é constituído pelas produções dos alunos da referida disciplina, e é composto de apresentações de seminários registrados em vídeos e relatórios escritos entregues como trabalho final da disciplina. Ambos, relatórios escritos e seminários, apresentaram análises de materiais de mídia sobre ciência e, por fim, a proposição de planos de aula que buscassem a inserção desses materiais em aulas de física. Ao todo, 19 licenciandos, distribuídos em cinco grupos, apresentaram seus trabalhos. Este material coletado foi analisado à luz do referencial metodológico da análise textual discursiva, particularmente como proposto por Moraes (2003) e Moraes e Galiazzi (2006).

Para identificar os materiais, usaremos a primeira letra como um indicativo se o trecho selecionado é proveniente de vídeo ou texto, usando respectivamente as letras $\mathrm{V}$ e $\mathrm{T}$. Além disso, usaremos a sigla da disciplina: EDC. Por último, usaremos números de 1 a 5 para identificar cada um dos grupos. Por exemplo: VEDC2 identifica um trecho selecionado do vídeo da apresentação do grupo 2 da disciplina EDC. Abaixo organizamos cada grupo por seus temas. Nota-se que a liberdade de escolha dos materiais possibilitou o surgimento de temas que normalmente não figuram nos currículos tradicionais de física:

Tabela 1 - Temas científicos presentes nos materiais de mídia selecionados pelos licenciandos.

\begin{tabular}{|c|c|}
\hline Grupo & Tema \\
\hline EDC1 & Acidentes nucleares \\
\hline EDC2 & Vida em Lua de Júpiter \\
\hline EDC3 & Ondas Gravitacionais \\
\hline EDC4 & Ondas Gravitacionais \\
\hline EDC5 & Aquecimento Goblal: o caso Climategate \\
\hline
\end{tabular}




\section{III.3 Referencial metodológico}

A análise dos materiais selecionados se deu fundamentalmente em uma perspectiva qualitativa, a partir do referencial metodológico da análise textual discursiva. De acordo com Moraes (2003), toda análise concretiza-se a partir de um conjunto de documentos denominado corpus. $\mathrm{O}$ autor defende que a análise textual qualitativa pode ser compreendida como um processo auto-organizado de construção de compreensão em que novos entendimentos emergem de uma sequência recursiva de três elementos: "desconstrução dos textos do corpus, a unitarização; estabelecimento de relações entre os elementos unitários, a categorização; o captar do novo emergente em que a nova compreensão é comunicada e validada" (MORAES, 2003, p. 192).

Uma das características centrais da análise textual discursiva, a nossa ver, é a consideração de que os textos que compõem o corpus da pesquisa não são produções estáticas que carregam um significado a ser apenas identificado. Pelo contrário, são significantes que exigem que o leitor ou o pesquisador construa significados com base em suas teorias e pontos de vista. Isso exige que o pesquisador se assuma como autor das interpretações que constrói dos textos que analisa.

A seguir apresentamos a sequência recursiva proposta pelo autor: unitarização, categorização e captação do novo emergente.

\section{III.3.1 Desmontagem dos textos: desconstrução e unitarização}

O primeiro passo da análise, como proposto pelo autor, é o que ele chama de "desmontagem do texto". Significa colocar o foco nos detalhes e nas partes componentes do texto, um processo de divisão que segundo o autor toda análise implica. Dessa desconstrução surgem as unidades de análise. É fundamental que seja reconhecido pelo pesquisador em quais contextos e quais documentos deram origem a cada unidade de análise. Para isso, usamse códigos que indicam a origem de cada unidade.

$\mathrm{O}$ autor defende a necessidade de um intenso contato e impregnação com o material de análise, e entende que essa impregnação passa por um processo de desorganização e desconstrução, para que possam surgir novas compreensões. $\mathrm{O}$ autor toma como referência as ideias dos sistemas complexos que consistem, segundo ele, em levar o sistema semântico ao limite do caos.

A partir da unitarização cria-se possibilidade de emergência de interpretações criativas, que estarão relacionadas ao escopo teórico que guia todo o processo. Parte fundamental para tais interpretações é categorizar as unidades de análise, sejam por categorias a priori ou categorias emergentes do próprio corpus, ou, ainda, um misto entre as duas possibilidades. Isto é, categorias que surgem a priori, mas que vão sendo modificadas a partir da "impregnação" com o corpus da pesquisa e, especialmente, com as unidades de análise. 


\section{III.3.2 Categorização}

O segundo momento do ciclo de análise é a categorização, cujo objetivo central é o agrupamento de elementos semelhantes. $\mathrm{O}$ autor afirma que no processo de categorização podem ser construídos diferentes níveis de categorias. Pode-se partir de diferentes métodos para a construção de categorias. Moraes destaca os métodos indutivo e dedutivo. O método dedutivo seria o movimento do geral para o particular, que implica construir categorias antes mesmo de examinar o corpus de textos, a partir das teorias que servem de fundamento para a pesquisa. Isto é, são categorias a priori. Por outro lado, o método indutivo constrói as categorias a partir das informações contidas no corpus de texto. É um caminho do particular para o geral, que resulta em categorias emergentes. Há ainda a possibilidade de combinar esses dois métodos, indutivo e dedutivo. Partindo de categorias definidas a priori com base em teorias previamente estabelecidas, "o pesquisador encaminha transformações gradativas no conjunto inicial de categorias, a partir do exame das informações do corpus de análise" (MORAES, 2003, p. 197).

Existem algumas propriedades que as categorias devem ter. Uma delas está relacionada à validade ou pertinência das categorias, isto é, devem ser válidas e pertinentes em relação aos objetivos e ao objeto de análise. Outra propriedade das categorias que o autor julga necessária, independente de seu método de produção, é a homogeneidade: "Não se pode misturar plantas e animais quando categorizando plantas" (MORAES, 2003, p. 199). Contudo, continua o autor, "é claro que é possível construir dois conjuntos de categorias complementares em que cada um deles tem um princípio classificatório diferente" (idem). Neste ponto, vale o parêntese com relação à categorização que empreendemos nesta pesquisa. Construímos três grupos de categorias de análise de nosso corpus: um grupo focado na análise da ciência, um focado na mídia e outro em processos de ensino. Esses grupos de categorias foram construídos a partir das fundamentações teóricas apresentadas na seção II e das interações empreendidas na disciplina analisada. Pretende-se que esses eixos sejam complementares na busca por compreender os fenômenos estudados envolvendo ciência, mídia e ensino. Partimos de categorias gerais e, a partir do contato com o material de análise, criou-se subcategorias específicas que emergiram do próprio material analisado.

Moraes antagoniza-se ao que chama "análises de conteúdo tradicionais" que exigem, segundo ele, que as categorias sigam um critério de exclusão mútua. A superação do critério de exclusão mútua, segundo o autor, é uma busca por superar o "reducionismo marcante em formas históricas de análise do conteúdo" (MORAES, 2003, p. 199). A ideia do autor é que as categorias sejam maneiras de focalizar o todo por meio das partes.

Se em um primeiro momento a ideia é fragmentar, desconstruir, isolar unidades de significado, na categorização busca-se "estabelecer relações, reunir semelhantes, construir categorias" (MORAES, 2003, p. 201). O objetivo desta etapa é produzir uma nova ordem para os materiais de análise, uma nova síntese. Não se pretende retornar aos textos originais, mas construir um novo texto, construir "um metatexto que tem sua origem nos textos originais, 
expressando um olhar do pesquisador sobre os significados e sentidos percebidos nesses textos" (idem).

Portanto, a etapa de categorização visa a construção de uma síntese analítica expressa em um metatexto, que constitui um conjunto de argumentos descritivos-interpretativos que expressam a compreensão do pesquisador em relação ao fenômeno estudado.

\section{III-c.3. Captando o novo emergente: a construção de metatextos}

$\mathrm{Na}$ análise textual discursiva "todo o processo de análise proposto volta-se à produção do referido metatexto" (MORAES, 2003, p. 202). Em nosso entendimento, a ideia de construção do metatexto relaciona-se à busca por compreender os pormenores das produções analisadas para que se busque uma articulação entre as compreensões permitidas por cada categoria, com o intuito de compreender/interpretar o fenômeno estudado de maneira mais ampla.

Esse terceiro estágio da análise textual qualitativa é a comunicação das novas compreensões atingidas ao longo dos dois estágios anteriores. A construção do metatexto é um processo reiterativo de reconstrução, no qual é "essencial a construção de um texto em que cada uma de suas categorias ou partes sejam perfeitamente integradas num todo" (MORAES, 2003, p. 208).

\section{Análise das produções dos licenciandos em física}

A seguir apresentamos um quadro organizado nos três eixos de análise e com categorias e subcategorias para cada um dos eixos. A última coluna deste quadro indica em quais materiais de nosso corpus são encontradas ocorrências que se enquadram em cada uma das subcategorias. A categorização está relacionada a aspectos mais amplos das produções dos grupos, enquanto as subcategorias têm a intenção de interpretar as particularidades das produções que compõem nosso corpus. Este quadro foi construído com base no referencial metodológico da análise textual discursiva e as categorias e subcategorias são fruto da fundamentação teórica apresentada na seção II e da impregnação com os dados que compõem o nosso corpus de análise.

Tabela 2 - Identificação de ocorrências dos grupos, de acordo com categorias e subcategorias de análise.

\begin{tabular}{|c|c|c|}
\hline Categorias & Subcategorias & Ocorrências \\
\hline \multicolumn{3}{|c|}{ Mídia } \\
\hline \multirow{3}{*}{$\begin{array}{l}\text { Contraditório e } \\
\text { confrontação de } \\
\text { diferentes materiais }\end{array}$} & Seleção de materiais com temáticas diferentes & Grupos 1 e 2 \\
\hline & $\begin{array}{l}\text { Seleção de materiais com mesma temática e } \\
\text { abordagens não conflituosas entre si. }\end{array}$ & Grupos 2, 3 e 4 \\
\hline & Seleção de materiais com mesma temática e & \\
\hline
\end{tabular}




\begin{tabular}{|c|c|c|}
\hline & abordagens conflituosas entre si & Grupo 5 \\
\hline Questão do Poder & Mídia "orquestrando" controvérsias & Grupo 5 \\
\hline \multirow{4}{*}{ Usos da Linguagem } & Hiperlinks & Grupo 3 \\
\hline & Discursos indiretos & Grupo 1 \\
\hline & Analogias & Grupo 4 \\
\hline & Simplificação & Grupos $1,3,4$ e 5 \\
\hline \multicolumn{2}{|l|}{ Sensacionalismo } & Grupos 1,4 e 5 \\
\hline \multicolumn{3}{|c|}{ Ciência } \\
\hline \multirow{5}{*}{$\begin{array}{l}\text { Relações entre Ciência, } \\
\text { Tecnologia e Sociedade }\end{array}$} & Credibilidade da Ciência na Sociedade & Grupo 1 \\
\hline & Financiamento científico & Grupo 2 e 3 \\
\hline & Interferência política na prática científica & Grupo 5 \\
\hline & Aplicações e desenvolvimento tecnológico & Grupos 2,3 e 4 \\
\hline & Questões Éticas & Grupo 5 \\
\hline \multirow{3}{*}{$\begin{array}{l}\text { Aspectos } \\
\text { Epistemológicos }\end{array}$} & Mito do Gênio & Grupos 4 e 5 \\
\hline & Cooperação internacional na Ciência & Grupo 2 \\
\hline & Papel do Experimento na Ciência & Grupo 3 \\
\hline \multicolumn{3}{|c|}{ Ensino } \\
\hline \multirow{4}{*}{ Problematização } & Problematização da Mídia & Grupos 4 e 5 \\
\hline & Problematização da Ciência & Grupo 3 \\
\hline & Problematização da Mídia e da Ciência & Grupo 5 \\
\hline & Ausência de problematizações & Grupo 1 \\
\hline \multirow{2}{*}{$\begin{array}{l}\text { Relação Professor- } \\
\text { Conhecimento-Aluno }\end{array}$} & Relação dialógica & Sem ocorrências \\
\hline & Relação expositiva & Grupos $1,2,3,4$ e 5 \\
\hline \multirow{2}{*}{$\begin{array}{l}\text { Seleção de } \\
\text { conhecimentos } \\
\text { Científicos }\end{array}$} & $\begin{array}{l}\text { Seleção de conteúdos científicos tradicionais } \\
\text { contextualizados }\end{array}$ & Grupo 5 \\
\hline & Seleção de conteúdos científicos não tradicionais & Grupos $1,2,3$ e 4 \\
\hline
\end{tabular}

A seguir apresentamos os resultados obtidos a partir de nossa análise, apresentando extratos das produções dos licenciandos, provenientes tanto dos relatórios quanto dos vídeos que compõem nosso corpus.

\section{IV.1 Categorização: Foco na Mídia}

Nesta seção focaremos no eixo da mídia e, na sequência, faremos o mesmo para os eixos da ciência e do ensino. Após este processo de organização dos textos de nosso corpus em categorias, apresentaremos nossas interpretações em um metatexto construído com base no processo de categorização, de impregnação com os dados e em aspectos teóricos apresentados neste trabalho. 


\section{IV.1.1 Contraditório e Confrontação de diferentes materiais}

A seleção de mais de um material sobre o tema selecionado por cada grupo era uma exigência da atividade sugerida aos licenciandos. Exigiu-se que fossem selecionados, no mínimo, dois materiais diferentes para um mesmo tema. Dos cinco grupos, apenas o grupo 5 selecionou mais de dois materiais. Desdobramos essa categoria em três subcategorias: seleção de materiais com temáticas diferentes; Seleção de materiais com mesma temática e abordagens não conflituosas entre si; Seleção de materiais com mesma temática e abordagens conflituosas entre si.

\section{Seleção de materiais com temáticas diferentes}

Os grupos 1 e 2 selecionaram reportagens que, a rigor, abordavam temas diferentes. Assim, a ideia de confrontar diferentes perspectivas não poderia se concretizar. $\mathrm{O}$ grupo 1 selecionou uma notícia que versava sobre o acidente em Fukushima e outra notícia sobre as bombas atômicas de Hiroshima e Nagasaki e do acidente em Chernobyl. O grupo 2 selecionou uma reportagem sobre estudos desenvolvidos acerca de eventuais tipos de vida que poderiam existir na Europa, lua de Júpiter, e que versava particularmente sobre investigações de bactérias extremófilas como as encontradas em uma mina de ouro na África do Sul. A outra notícia versava sobre o anúncio de uma missão da NASA à Europa, lua de Júpiter. Embora as reportagens selecionadas pelos grupos 1 e 2 tenham pontos de intersecção, não permitem o exercício crítico de confrontar diferentes pontos de vistas, simplesmente porque não versam sobre o mesmo tema. Também chama atenção, com relação à possibilidade de confrontação, que o grupo 1 selecionou duas reportagens do mesmo canal de comunicação, BBC Brasil.

A confrontação feita pelo grupo 1 fica restrita à forma como ambas as reportagens selecionadas não apresentam de maneira adequada suas referências.

\footnotetext{
Uma coisa curiosa que acontece nas duas noticias é que eles não dão referências, não dão contrapontos. Focam, principalmente na primeira notícia, nos especialistas. Toda hora eles falam: os especialistas afirmam...especialistas disseram tal coisa. Mas quem são esses especialistas? É um grupo de engenheiros e físicos? Ou pegou de algum outro lugar? Eles nunca citam. Então eles cozinham a gente pra ler a notícia e só acreditar, como se a gente não fosse questionar. Não cabe a gente questionar, porque não tem nem como a gente ir atrás. De onde tirou essa notícia? Ou pelo menos, de onde tiraram este estudo? (VEDC1).
}

\section{Seleção de materiais com mesma temática e abordagens não conflituosas entre si}

Em sua análise, o grupo 2 buscou comparações entre produções que, como apontamos anteriormente, não abordavam a mesma temática, embora com intersecções entre si. Contudo, o grupo 2 aponta em sua análise uma reportagem publicada no site da Globo, na qual o mais influente conglomerado de comunicação do país reproduz o texto publicado pela 
BBC. A rigor a comparação entre esses dois materiais, que são exatamente o mesmo, indica um processo de homogeneização das produções midiáticas sobre ciência.

A propagação da ciência por alguns meios de comunicação são basicamente "ctrl + c e ctrl $+v$ ", onde não há uma leitura prévia para a publicação de tal notícia. Exemplo do que foi citado é a replicação da notícia da BBC no site da Globo (Ciência e Saúde) - link da notícia replicada, para caráter de curiosidade é http://g1.globo.com/ciencia-e-saude/noticia/2014/03/nasa-anuncia-missao-paralua-de-jupiter-que-pode-ter-vida.html-, onde até mesmo o erro gramatical encontrado ("Ciensitas") foi replicado sem a devida correção (TEDC2).

O grupo 4 compara diretamente os materiais selecionados, em busca de compor uma visão mais complexificada do tema abordado. A este respeito afirmam o seguinte:

[...] pode-se destacar que em ambos os textos encontram-se exageros e distorções das informações sobre a proporção das ondas encontradas, pois nos dois textos são citadas proporções diferentes, e isso pode causar confusão ao leitor ao querer conhecer um valor próximo, já que esses são sites bem conceituados na sociedade. (TEDC4).

Seria impossível saber se os dados apresentados, as ordens de grandeza, as proporções, etc. são adequadas se não fosse feita uma confrontação entre materiais diferentes. Nesta crítica específica, a comparação entre dois materiais também não soluciona o problema, embora o identifique. Assim, seria importante a confrontação dos dados apresentados em ambas as reportagens com uma terceira, além da confrontação com fontes primárias: neste caso os artigos científicos publicados sobre a detecção das ondas gravitacionais.

\section{Seleção de materiais com mesma temática e abordagens conflituosas entre si}

O grupo 5 lidou com o exercício crítico da confrontação entre pontos de vistas de maneira mais consciente e explícita, se comparado aos demais grupos. Chama atenção que este foi o único grupo que descreveu características dos canais de comunicação selecionados e teceu considerações sobre como essas características implicam na forma como constroem seus argumentos e defesas. Assim, intencionalmente o grupo selecionou um material que teria propensão a defender os cientistas acusados de manipular os dados sobre mudança climática e outro material que tenderia a atacar os cientistas e a ideia de um aquecimento global antropocêntrico.

A Scientific American é uma revista de divulgação cientifica. Então, obviamente, ela ia sair em defesa aos cientistas. Então, já que a gente pegou um revista que defende tanto os cientistas, deixa eu pegar uma que vai atacar, com certeza. [Pegamos] um jornal do Reino Unido, extremamente conservador [The Telegraph]. (VEDC5) 


\section{IV.1.2 Exercício do poder}

Dos cinco grupos, apenas um considerou diretamente a questão do poder relacionado à mídia. Em particular, o grupo 5 usou a fala de um político afirmando que a controvérsia acerca dos e-mails dos climatologistas que foram vazados no caso climategate havia sido orquestrada por parte da mídia. O grupo considera as implicações que as narrativas da mídia podem desempenhar na visão de mundo das pessoas.

A mídia tem uma parte muito importante na moldagem do pensamento do publico,
ou seja, a circulação de tal acontecimento, trazendo alegações precipitadas, mas
não fazendo o mesmo furdunço livrando os cientistas não envolvidos, e isso foi uma
preocupação geral já que isso poderia implicar no julgamento de uma comunidade
inteira de cientistas (TEDC5).

Chama atenção que os licenciandos se posicionam diante do tema abordado, criticando a maneira como parte da mídia tratou o caso climategate, em particular pelo ataque à credibilidade do trabalho de alguns cientistas. $O$ grupo 5 ainda critica de maneira mais incisiva o jornal The Telegraph, classificando-o como extremista.

\section{IV.1.3 Usos da Linguagem}

\section{Hiperlinks}

Uma característica de usos da linguagem que surgiu entre as análises dos grupos foi algo próprio das produções digitais e que se configura como um recurso tecnológico interessante: uso de hiperlinks. O grupo chama atenção, portanto, de um recurso que as produções midiáticas online usam para que seus leitores possam, a qualquer momento, aprofundar em pontos específicos do texto através de links diretos a outros textos.

\section{Discursos indiretos}

O grupo 1 identificou como um dos recursos de linguagem utilizados nos materiais que analisaram o uso de discursos indiretos, usando principalmente a autoridade dos cientistas para construir enunciações com locutores tidos como especialistas. $\mathrm{O}$ grupo critica este uso como forma de apresentar um "verniz de verdade" aos enunciados presentes na mídia.

\section{Analogias}

Outra característica linguística identificada pelos licenciandos nas produções midiáticas foram as analogias. Este é um recurso recorrente, em particular na busca pela reconstrução do discurso da ciência para o público geral. 


\section{Simplificação}

A simplificação é uma das características mais apontadas pelos licenciandos em suas análises dos materiais midiáticos selecionados. O próprio contexto em que estão inseridos, formação de futuros professores de física, faz com que apontem a falta de conceitos científicos nos materiais analisados e suas supostas abordagens superficiais.

[...] como estamos estudando licenciatura em Física é importante a gente deixar claro que lá não vai explicar Física, os caras só vão falar superficialmente (VEDC1).

Os apontamentos dos licenciandos estão atrelados recorrentemente à insuficiente abordagem dada aos conceitos científicos. Em nosso corpus temos alguns exemplos desses apontamentos, por exemplo, na análise do grupo EDC1, que associa o processo de simplificação à apresentação de conceitos científicos de maneira errônea.

A linguagem do texto é muito simplificada, ao ponto de ser questionável (TEDC1).

O grupo 1 também chama atenção de que esse processo de simplificação está atrelado à busca, legitima em nossa opinião, por aproximar o público leigo de assuntos da ciência.

\section{IV.1.4 Sensacionalismo}

Em nosso corpus temos exemplos de análises que indicam o uso do sensacionalismo em materiais selecionados pelos licenciandos. Esses apontamentos se dão de maneiras diferentes. Por um lado, o grupo 1 conclui que os materiais que selecionaram se comprometeram apenas com a publicidade do evento científico, relacionados a acidentes nucleares, apelando, principalmente, para os impactos de destruição causados pela energia nuclear liberada no acidente de Fukushima, Chernobyl e relacionados às bombas atômicas lançadas sobre Hiroshima e Nagasaki. O grupo 4, por sua vez, chama atenção do uso do sensacionalismo na maneira como projeta a imagem de Einstein ao abordar o tema das ondas gravitacionais. É um sensacionalismo pautado na imagem distorcida sobre o cientista, relacionada ao mito do gênio.

\section{IV-b. Categorização: Foco na Ciência \\ IV.2.1 Relações CTS}

A análise de nosso corpus nos levou a interpretar que a própria seleção dos temas empreendida pelos grupos teve como critério os impactos sociais, tecnológicos e ambientais relacionados à ciência. Esta busca por aproximar a ciência de questões com relevância social é uma característica da própria mídia, que busca sempre a maior audiência possível e, portanto, produz seus materiais de modo que tenham impacto sobre os possíveis leitores, telespectadores, ouvintes etc. 
O grupo 1 selecionou o tema de acidentes e bombas nucleares. O grupo 2 selecionou o tema de vida extraterrestre que, além de envolver questões existenciais como a possibilidade de vida fora de nosso planeta, lida com questões de avanços tecnológicos de ponta para o lançamento de sondas espaciais. Os grupos 3 e 4 selecionaram o tema das ondas gravitacionais. Este é o tema que a priori parece ser mais interno à própria ciência. Contudo, tem uma série de relações com a sociedade, como o financiamento dos laboratórios que detectaram as ondas, os desdobramentos relacionados ao prestígio alcançado pelos cientistas envolvidos, sobretudo através de premiações como o Nobel, além de perspectivas de desenvolvimento de novas tecnologias atreladas às ondas gravitacionais. $O$ grupo 5 selecionou um evento controverso sobre o vazamento de emails de climatologistas, que colocou em debate a credibilidade da ciência na sociedade, além de estar relacionado a questões climáticas, que tem sido uma das principais preocupações entre cientistas, políticos e cidadãos.

Em nosso corpus, considerando os 5 grupos, temos a presença de diferentes aspectos relacionados a relações entre Ciência, Tecnologia e Sociedade, tais como sobre a credibilidade da Ciência na sociedade, questões sobre financiamento, questões éticas, investigação e interferência política na prática científica, aplicações e desenvolvimento tecnológico.

\section{Interferência política na prática científica}

Com relação à interferência política na prática científica, o grupo 5 destaca a fala do político britânico Lord Lawson, cobrando apurações sobre a possível manipulação de dados climáticos para defender a interpretação de um aquecimento global antropocêntrico.

Nos Estados Unidos e na Inglaterra foram solicitados pedidos de investigações oficiais, já que certos assuntos discutidos nos e-mails mexiam com questões diplomáticas. O político conservador britânico Lord Lawson disse: "A integridade da evidência científica... tem sido questionada. E a reputação da ciência britânica tem sido seriamente prejudicada. Uma investigação independente de alto nivel deve ser realizada sem demora" (TEDC5).

Este extrato da análise feita pelo grupo 5 mostra como destacaram os desdobramentos da ciência na organização social, particularmente relacionada à classe política da Inglaterra, onde ocorreu o caso dos vazamentos dos emails. Frisam que a interferência política foi feita por um conservador, supostamente preocupado com a integridade da evidência científica. Esta interferência está diretamente ligada, portanto, à preocupação com a credibilidade da ciência entre os cidadãos e cidadãs. 


\section{Credibilidade da Ciência na Sociedade}

O grupo 5 usa o caso climategate, e a análise que fizeram dos materiais selecionados, para discutir a credibilidade da ciência entre os cidadãos, que poderia ser questionada a partir da eventual manipulação de dados a que estavam sendo acusados os cientistas. A este respeito citam uma pesquisa de 2010 feita pela Universidade de Yale sobre os efeitos do caso Climategate sobre a confiança das pessoas nos cientistas e na ciência.

O diretor do Projeto da Universidade de Yale sobre Mudança Climática A. A. Leiserowitz e seus colegas descobriram em 2010 que: "Climategate teve um efeito significativo sobre as crenças públicas no aquecimento global e confiança nos cientistas. A perda de confiança nos cientistas, no entanto, foi principalmente entre indivíduos com visão de mundo fortemente individualista ou ideologia politicamente conservadora. No entanto, os americanos em geral continuam a confiar nos cientistas mais do que em outras fontes de informação sobre o aquecimento global." (TEDC5).

Este caso pode produzir perda de confiança na ciência por parte dos cidadãos, como indicou a pesquisa mostrada pelo grupo 5, e abrir discussões sobre a prática científica, particularmente relacionadas a posturas éticas dos pesquisadores que supostamente teriam manipulado dados para defenderem sua tese.

\section{Questões Éticas}

Com relação à postura ética dos cientistas, o grupo 5 destaca o pronunciamento da Sociedade Meteorológica Americana, que defende que há uma crescente obviedade da ação humana sobre o clima e que o caso dos emails vazados, mesmo se comprovadas as manipulações de dados, não seriam suficientes para desbancar essa compreensão.

Para a pesquisa sobre mudanças climáticas, o corpo de pesquisa na literatura é muito grande e a dependência de qualquer conjunto de resultados de pesquisa para a compreensão abrangente do sistema climático é muito, muito pequena. Mesmo que algumas das acusações de comportamento impróprio neste caso específico se revelem verdadeiras - o que ainda não é claramente o caso - o impacto sobre a ciência da mudança climática seria muito limitado (TEDC5).

Esta passagem destaca pelo menos duas características da dinâmica da ciência: primeiro que as compreensões construídas acerca de determinados fenômenos da natureza dependem da convergência de muitos trabalhos e não apenas de um conjunto de dados isolado. Segundo, que pode haver comportamentos impróprios entre os integrantes da comunidade científica, embora isso não deva desabonar a ciência como um todo. Em outras palavras, a ciência não está isenta de que parte de seus integrantes tenham desvios éticos em suas práticas. 


\section{Financiamento científico}

Em nosso corpus também são apresentadas considerações acerca do financiamento científico, e como o investimento em ciência é fundamental para a prática científica. O recorte em que esta questão fica mais evidenciada é na análise do grupo 3, quando comentam sobre o longo período desde a proposição das ondas gravitacionais no início do século XX, passando pelas primeiras ideias de experimento na década de 70 , culminando com sua detecção em 2016.

A parte mais intensa e diagnosticadamente importante da mensagem fica por conta da pergunta, "Porque demorou tanto", onde são levantados fatores relevantes, mesmos que implicitos, de que a ciência precisa de investimentos e que as descobertas precisam de uma sequência de estudos que, de forma constante, precisa do domínio financeiro para se ajustar. Essa elaboração mantém o crivo de que a descoberta só foi possivel porque houve investimentos para a melhoria do equipamento de deteç̧ão (TEDC3).

Esta passagem evidencia tanto a historicidade da ciência, enfatizando o longo período de construção de uma ideia, de um experimento, e enfatiza a necessidade de investimentos financeiros, principalmente para o desenvolvimento de experimentos cada vez mais sofisticados para a produção de conhecimento científico. Também podemos destacar o avanço tecnológico envolvido em experimentos, tais como os empreendidos no laboratório LIGO, que detectaram as ondas gravitacionais.

\section{Aplicações e desenvolvimento tecnológico}

Os avanços tecnológicos foram a principal relação CTS indicada pelo grupo 4, que também selecionou o tema das ondas gravitacionais. $O$ grupo 4 destaca não apenas os avanços tecnológicos envolvidos na elaboração experimental relacionada à detecção das ondas gravitacionais, como também projetam possíveis desdobramentos futuros, fazendo paralelo com a proposição de ondas eletromagnéticas que hoje fundamentam grande parte do funcionamento de aparatos tecnológicos usados pelos cidadãos e cidadãs. As possibilidades abertas com as ondas gravitacionais não se limitam a possibilidades tecnológicas, mas também abrem novas possibilidades de investigar o universo, como destacam os integrantes do grupo 3.

\section{IV.2.2 Aspectos epistemológicos}

Encontramos em nosso corpus exemplos de considerações epistemológicas nas análises dos licenciandos. São considerações a respeito da imagem que se faz do cientista, sobretudo buscando apontar a distorção relacionada ao mito do gênio. Além disso, são apresentadas considerações epistemológicas relacionadas a dinâmica de construção da ciência como um processo histórico e não linear e que perpassa disputas entre teorias; o papel do 
experimento na construção da ciência; a cooperação entre cientistas e a convergência na coleta de dados para o estudo de um fenômeno.

\section{Papel do Experimento na Ciência}

O grupo 3 critica a maneira como a Folha de SP retrata o papel dos experimentos realizados pelo LIGO na detecção das ondas gravitacionais. Em particular, criticam a passagem na qual o material analisado considera o experimento como a primeira detecção irrefutável das ondas gravitacionais. É justamente a consideração do experimento como irrefutável que o grupo criticou.

\section{Cooperação internacional na Ciência}

Ainda sobre a dinâmica de funcionamento da ciência, há no nosso corpus a consideração sobre a cooperação internacional da ciência. $O$ grupo 2 destaca a cooperação entre cientistas de diferentes países. Por sua vez, o grupo 3 critica a reportagem da FOLHA de $\mathrm{SP}$, por entenderem que essa produção supervalorizou a supremacia dos EUA nas descobertas científicas relacionadas às ondas gravitacionais.

\section{Mito do Gênio}

As discussões sobre o mito do gênio configuram-se como as principais considerações epistemológicas que constam em nosso corpus. Com relação ao tema das ondas gravitacionais, o grupo 4 critica a maneira como a mídia usa a imagem de Einstein em suas produções, sobretudo considerando que mais uma vez a história tratou de mostrar, através da detecção das ondas gravitacionais, a genialidade do físico alemão. No caso dos vazamentos dos emails de climatologistas, os licenciandos também chamam a atenção para a discussão sobre a imagem dos cientistas, sobretudo problematizando seu status de "ser perfeito" que não comete erros.

\section{IV.3 Categorização: Foco no Ensino}

Este eixo da análise tem como intenção interpretar as maneiras como os licenciandos propuseram seus planos de aula buscando a aproximação entre ciência e mídia. Focamos, sobretudo, em como propuseram a inserção dos materiais de mídia em aulas de física, quais objetivos educacionais declararam a partir desta inserção, a seleção e a organização de conhecimentos em sequências de aulas, e como projetaram o posicionamento dos alunos (se passivo ou ativo e criativo) diante dos materiais de mídia e diante dos próprios assuntos científicos abordados. 


\title{
IV.3.1 Problematização
}

\section{Problematização da Mídia e da Ciência}

Nosso corpus indica que alguns grupos consideraram a apropriação de conhecimento científico como meio de atuação no mundo.

\begin{abstract}
Em sala de aula, o mais importante é que o professor consiga incentivar seus alunos ao estudo da fisica, se não por interesse cientifico, para a construção de cidadãos críticos capazes de realizar a leitura de textos como estes e entender o que há nas entrelinhas, que busquem outras fontes de informação e consigam realizar suas próprias conclusões, sem a influência da opinião de um jornal, uma revista, um editor ou um cientista (TEDC5).
\end{abstract}

Este extrato aborda questões que consideramos importantes na aproximação entre a educação para as mídias e o ensino de ciências. Em primeiro lugar, enfatiza a importância de os próprios alunos desenvolverem suas visões de mundo, a partir de uma gama de fontes, tanto da mídia quanto da ciência. Além disso, enfatiza que a compreensão dos materiais de mídia passa por compreender as mensagens subentendidas que as compõem.

Outro indício de busca por problematização tanto da mídia quanto da ciência encontra-se na descrição do desenvolvimento do que seria a aula 2 do grupo 5, na qual propõem alguns questionamentos como estruturantes da aula 3 :

Ao final da aula [2], para pesquisa a ser aprofundada em debate na Aula 3, devem-
se levantar seguintes perguntas: Como eu sei que o que estou lendo é
verdadeiro? Como saber se a fonte da minha pesquisa é confiável?Como é o
trabalho do cientista? (TEDC5)

\section{Problematização da Mídia}

O grupo 3 indica como objetivos o desenvolvimento de posturas críticas diante da mídia. É possível inferir que os licenciandos compreendem que a apropriação de conhecimentos científicos é condição para a possibilidade de desenvolvimento de crítica aos materiais de mídia.

O objetivo dessas aulas será mostrar aos alunos que nem sempre o que está em uma mídia famosa é uma verdade absoluta, será importante nessas aulas que os alunos desenvolvam conhecimento sobre o assunto para que possam questionar informações cedidas pelo texto (TEDC3).

O entendimento de que apreender conhecimento científico é condição para a crítica da mídia fica ainda mais evidenciado na descrição da primeira aula, em uma sequência de quatro aulas, que propuseram em seu plano de aula.

Procurar instigar os alunos quanto ao conteúdo apresentado nos textos jornalísticos, a fim de procurar possiveis falhas nesses textos. Também procurar as 
raízes dessas pesquisas, para começar nas próximas aulas, a construir os caminhos que levaram até elas (TEDC3).

\section{Problematização da Ciência}

O grupo 5, embora tenha proposto a problematização da mídia, destacando entre outras coisas a leitura das "entrelinhas" das produções midiáticas e de questionamentos sobre a dinâmica de produção da mídia, foca sobretudo na problematização da própria ciência.

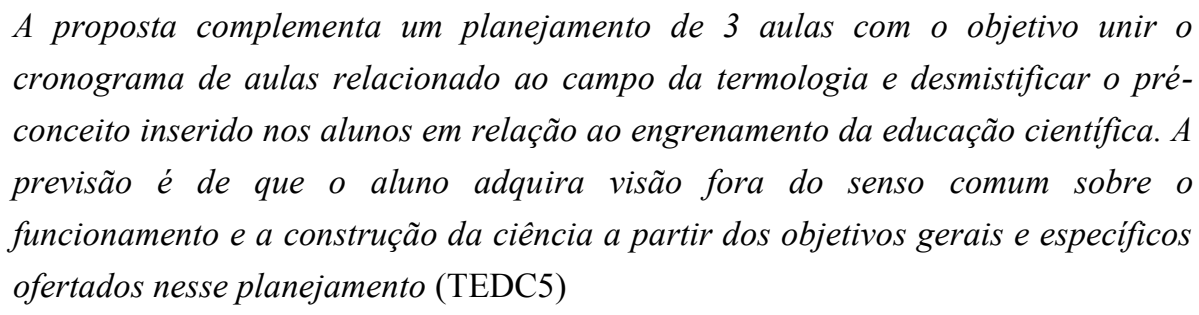

O grupo 4 também prioriza a problematização da ciência, em particular ao enfatizar o caráter construtivo e histórico deste conhecimento.

O objetivo de esclarecer o tecido espaço-tempo aos alunos é para mostrá-los que, na física, existem diversas teorias que tentam explicar o mesmo fenômeno; que não há somente uma teoria que é a "verdade absoluta" e que explica exatamente tudo o que ocorre. Neste caso, o conceito do tecido espaço-tempo serve como uma alternativa ao modelo gravitacional de Newton, que é o modelo mais comumente ensinado em escolas de ensino médio (TEDC4).

\section{Ausência de problematizações}

O grupo 1 apresentou seu plano de aula sem indícios de problematizações, tanto da ciência quanto da mídia. De maneira geral, propuseram como objetivos a explicação sobre energia renovável e não renovável e os conceitos de fissão e fusão nucleares. Isto é, um ensino focado apenas nos conteúdos.

\section{IV.3.2 Relação Professor-Conhecimento-Aluno}

\section{Relação expositiva}

A análise de nosso corpus indicou que a maior parte dos grupos planejou suas aulas de modo que os alunos fossem colocados em posições passivas, os quais teriam a função de compreenderem as relações que são objetivadas a partir, principalmente, de aulas expositivas, como exemplificado pelo extrato do grupo EDC1 a seguir:

Explicar em aula expositiva o conteúdo das reportagens em três blocos: Acidentes Nucleares, Bomba Atômica e Princípios de "Fissão" e "Fusão Nuclear", explanando sobre os principais aspectos dos fatos e fenômenos (TEDC1). 


\section{IV.3.3 Seleção de conhecimentos Científicos}

A partir da análise de nosso corpus é possível verificar que os licenciandos propuseram temas que normalmente não figuram em currículos tradicionais de física. Houve, sobretudo, uma predileção por temas atuais que envolvessem a física, tais como energia nuclear, questões climáticas, ondas gravitacionais e o lançamento de sondas espaciais.

\section{Seleção de conteúdos científicos tradicionais contextualizados}

Apenas o grupo 5 selecionou conhecimentos que consideramos tradicionais, isto é, conhecimentos físicos que normalmente figuram nos currículos escolares. Para discutirem o caso do climategate, os licenciandos propuseram uma primeira aula para discutirem termologia, em particular sobre escalas termométricas e diferenciação entre temperatura e calor.

Vale notar, contudo, que a seleção de conhecimentos não se restringe aos conteúdos e teorias científicas, mas, também, conhecimentos acerca do fazer científico. Isto é, ensinar/aprender ciência é mais do que apenas dominar os conteúdos científicos em si. Neste sentido, o grupo 5 selecionou, além de conteúdos de termologia, conhecimentos sobre $\mathrm{NdC}$, com o objetivo de problematizar o fazer científico a partir do caso climategate.

\section{Seleção de conteúdos científicos não tradicionais}

Os grupos 1, 2, 3 e 4 selecionaram conteúdos que consideramos como não tradicionais, isto é, que normalmente não figuram nos currículos de física. O grupo 1 selecionou episódios relacionados à energia nuclear, tema ligado à física moderna e que já vem sendo indicado por pesquisadores e por currículos há pelo menos duas décadas. O grupo 2 selecionou um tema interdisciplinar, no qual o foco principal são os estudos sobre a possibilidade de vida extraterreste. Este tema inclui conhecimentos de Física, Biologia e Química, além de conhecimentos atrelados ao desenvolvimento tecnológico na construção de sondas espaciais. Os grupos 3 e 4 selecionaram o tema das ondas gravitacionais.

Nos materiais que compõem nosso corpus não ficam claras quais metodologias seriam empreendidas para a inserção dos materiais de mídia durante as aulas de física. Temos apenas indícios genéricos sobre tais inserções. Em geral, nosso corpus indica que os licenciandos apresentaram preferência por inserir os materiais midiáticos após uma sequência de aulas que introduzissem determinados temas, como forma de exemplificar os conteúdos trabalhados. Além disso, a estratégia mais presente em relação à inserção dos materiais de mídia, e avaliação dos alunos, é através da produção de textos, como destacado no extrato do plano de aula do grupo EDC3 a seguir:

Para avaliar os alunos, será proposto que eles escrevam um texto criticando os pontos positivos e negativos dos textos jornalísticos. (TEDC3). 
O resultado que consideramos mais importante deste eixo de análise foi que os licenciandos tiveram dificuldades em propor planos de aulas que fossem coerentes com a análise que empreenderam dos materiais selecionados. Em geral, propuseram aulas que priorizavam exposições e com avaliações que também não enfatizaram possíveis contribuições criativas dos alunos. Vale destacar que EDC é a primeira disciplina de ensino que os alunos têm contato em seu currículo da licenciatura em física.

\section{IV.4 Interpretações a partir das categorizações: construindo um metatexto}

Uma das compreensões a que chegamos ao desmontar os textos dos licenciandos em unidades de análise e categorizá-los foi que houve pouca confrontação entre os materiais de diferentes meios de comunicação que selecionaram. Em paralelo à dificuldade em confrontar os materiais midiáticos, entendemos que apresentaram descrições pobres dos meios de comunicação dos quais foram selecionados os materiais analisados pelos grupos. Em geral, os grupos se limitaram a apresentar os títulos das reportagens selecionadas e os canais de comunicação nos quais foram publicadas. Pouca ou nenhuma atenção foi dada às datas de publicações; se as reportagens eram assinadas por uma pessoa, pela redação ou por uma agência de notícias; se o canal de comunicação era público ou privado, se faziam parte de grandes conglomerados. Como chamamos a atenção na fundamentação teórica apresentada na seção II, com base principalmente na epistemologia freireana, as produções midiáticas não são neutras e sim tributárias de seus contextos. Assim, caracterizar os meios de comunicação é condição indispensável para se compreender as construções de argumentos, as defesas de pontos de vista, etc. Além disso, entender os possíveis usos de poder passa por identificar os lugares de fala, os eventuais interesses políticos e econômicos de quem produzem as mensagens que circulam na mídia, o que foi pouco explorado pelos grupos em geral.

Nossa análise indica, também, que os licenciandos produziram análises que problematizaram algumas características relacionadas à produção da mídia. Por exemplo, os licenciandos indicaram em suas análises o uso de discursos indiretos como forma de usar a autoridade do cientista nos discursos produzidos pela mídia. Este recurso discursivo é amplamente usado pela mídia na construção de suas narrativas. Fala-se através dos especialistas. É comum usar discursos indiretos na construção de enunciações. Como afirma Zamboni (2001), a enunciação do discurso científico aparece recorrentemente "sob a forma do discurso indireto Fulano diz que..., em que o nome dos enunciadores, seu estatuto de especialistas e o tempo de enunciação são especificados com abundância e rigor" (ZAMBONI, 2001, p.52). A autora defende que o uso do discurso indireto dos cientistas empresta ao discurso da divulgação científica, e da mídia no nosso caso específico, um "'efeito de real' do discurso da ciência, ao mesmo tempo em que lhe assegura a autoridade e a seriedade da voz que 'diz a verdade'"(idem).

Além do uso de discursos indiretos pela mídia, o principal apontamento dos licenciandos é que a mídia sobre ciência produz simplificações da linguagem da ciência, em 
acordo com as indicações de Ribeiro e Kawamura (2008) presentes na seção II deste trabalho. Um dos grandes desafios dos jornalistas, particularmente para àqueles que produzem materiais sobre ciência, é lidar com a construção de um discurso para o público amplo a partir de um discurso especializado. A tarefa do jornalista, e do divulgador da ciência de maneira geral, não se restringe a uma mera tradução, mas passa por uma reinterpretação entre discursos. Este processo, contudo, pode levar a simplificações demasiadas, como indicaram os licenciandos.

A simplificação foi a característica mais apontada pelos licenciandos em nosso corpus. Interpretamos que isso se deve ao próprio contexto em que estão inseridos esses professores em formação. Como alunos de segundo semestre em um curso de licenciatura em física, a expectativa é que suas formações devem estar relacionadas a uma apropriação profunda, e não simplificada, do conhecimento físico. O que, embora não seja suficiente, julgamos ser fundamental. Também foi recorrente na análise dos licenciandos o apontamento de abordagens sensacionalistas da ciência. Esta é uma característica marcante das produções midiáticas sobre a ciência, como apontado por Teixeira (2002) e Ribeiro e Kawamura (2008).

Com relação à aproximação entre as perspectivas da mídia e do ensino de ciências, a análise de nosso corpus nos levou a interpretar que a própria seleção dos temas empreendida pelos grupos teve como critério os impactos sociais, tecnológicos e ambientais relacionados à ciência. Esta busca por aproximar a ciência de questões com relevância social é uma característica da própria mídia, que busca sempre a maior audiência possível e, portanto, produz seus materiais de modo que tenham impacto sobre os possíveis leitores, telespectadores, ouvintes etc.

Como a mídia normalmente aborda assuntos contemporâneos e com apelo aos interesses de um público amplo, verificamos que os temas e conhecimentos propostos nos planos de aulas dos licenciandos de EDC normalmente não figuram em currículos tradicionais de física. Houve, sobretudo, uma predileção por temas atuais que envolvessem a física, tais como energia nuclear, questões climáticas, ondas gravitacionais e o lançamento de sondas espaciais.

Entendemos que inserir a mídia no ensino de física permitiu aos licenciandos selecionar conhecimentos, tradicionais ou contemporâneos, que não tinham fins em si mesmos. Isto é, a inserção da mídia permitiu a proposição de aulas nas quais o conhecimento físico é apresentado de forma contextualizada. Além disso, nossa análise indica que a forma como a mídia aborda a ciência possibilita problematizações sobre a própria produção da ciência. Os licenciandos destacaram, entre outros aspectos, a forma como a mídia trata o papel dos experimentos na construção do conhecimento, o mito do gênio, questões sobre o financiamento da ciência, questões controversas como o vazamento de emails sugerindo a manipulação de dados por parte de cientistas etc. Discutir questões sobre a ciência vem sendo indicado nas pesquisas atuais em ensino de ciências, sobretudo para formar cidadãos e cidadãs que sejam aptos a compreenderem a dinâmica da ciência, em busca de posturas críticas em 
momentos de decisões, pessoais ou coletivas (ALLCHIN, 2013; BAGDONAS; ZANETIC; GURGEL, 2014; MARTINS, 2015).

Por fim, destacamos que o conjunto de dados que compõe nosso corpus indicou que embora os licenciandos tenham desenvolvido críticas bem elaboradas tanto da mídia quanto da ciência, não conseguiram concretizar em seus planos de aulas situações que houvesse problematizações tanto da mídia quanto da ciência. Além disso, em geral os grupos desconsideraram as capacidades criticas e criativas dos alunos que eventualmente seriam impactados pelos planos de aulas desenvolvidos. Houve uma predileção por uma relação professor-conhecimento-aluno unidirecional, do professor para o aluno, em abordagens expositivas do conhecimento científico e das críticas à mídia. Interpretamos isto como uma tensão normal pela qual licenciandos em início de formação devem ser submetidos, já que grande parte tem introjetada em si uma cultura escolar que prioriza o professor como detentor de conhecimento e o aluno como tabula rasa que deve ser preenchido e moldado.

Notou-se, assim, que embora tenham empreendido análises críticas dos materiais midiáticos selecionados, os licenciandos usaram esses materiais como meros instrumentos para, ao final e ao cabo, ensinar conceitos científicos, desprezando a característica desses materiais "como processos que determinam - em diálogo ou tensão com outras instituições socializadoras - a forma como se constrói o pensamento e o conhecimento hoje e a forma com que os indivíduos se relacionam entre eles e com o mundo" (PRAZERES, 2009, p.7). De acordo com a análise empreendida, as proposições de aulas desenvolvidas pelos licenciandos priorizaram a exposição, do professor para o aluno, em vez de abordagens problematizadoras e emancipadoras como preconizadas pela perspectiva freireana. Este resultado não implica uma crítica à disciplina ou, menos ainda, aos licenciandos. Em nossa leitura, este resultado demonstra o desafio de desenvolvimento e implementação de novas práticas de ensino envolvendo perspectivas educacionais humanistas na busca por aproximar questões relacionadas à mídia e à ciência.

\section{Considerações finais}

As principais características dos materiais midiáticos envolvendo a ciência indicadas pelos licenciandos foram a simplificação e o sensacionalismo. Em relação às características da ciência na mídia, exploraram, sobretudo, o mito do gênio e a supervalorização do papel do experimento na construção da Física.

A partir da análise do corpus deste trabalho, percebemos que a aproximação entre as perspectivas da educação para as mídias e o ensino de ciências enfrenta tensões, principalmente, entre os fundamentos educacionais e as condições concretas nas quais os professores em formação estão inseridos. A análise dos materiais desenvolvidos pelos licenciandos indicou que embora eles tenham, em geral, desenvolvido análises críticas dos materiais midiáticos selecionados, não conseguiram propor planos de aulas que buscassem a problematização das questões levantadas em suas críticas. Houve uma busca sistemática por 
aprofundar os conhecimentos físicos divulgados de forma superficial por materiais de mídia. Este resultado evidencia os desafios de se desenvolver e implementar novas práticas educacionais pautadas em referenciais humanistas.

A partir da análise dos materiais desenvolvidos pelos professores em formação, concluímos que faltaram atividades direcionadas no desenvolvimento da disciplina, nas quais eles pudessem analisar mais materiais midiáticos de variados temas, de preferência sugeridos por eles próprios, confrontando materiais, pesquisando de maneira metódica a constituição dos meios de comunicação do Brasil e do mundo, já que a falta de caracterização dos materiais selecionados pelos licenciandos mostra que esta foi uma prática pouco explorada na disciplina ministrada. Não basta dizer que a confrontação de materiais e a caracterização da mídia são fundamentais para o desenvolvimento de posturas críticas, é necessário criar condições concretas para que isto seja possível.

Por fim, no atual contexto de pós-verdade tem surgido um movimento de legisladores, formadores de opinião e da própria mídia, para propor iniciativas de controle do que pode e o que não pode ser publicado. Mesmo que a intenção seja das melhores, "entregar essa responsabilidade para empresas privadas, praticamente monopolistas, é um risco enorme para a liberdade de expressão" (GENESINI, 2018, p. 51). Por isso, em vez de controle e censura do que é produzido pela mídia, defendemos que a educação seja o melhor caminho para que cidadãs e cidadãos estejam preparados para lidar com a mídia no atual contexto de pós-verdade. Portanto, iniciativas concretas e pontuais de problematização da mídia na educação científica, como a empreendida neste trabalho, e discussões curriculares mais amplas para estruturar proposições de novas iniciativas educacionais, são urgentes.

\section{Agradecimento}

Agradeço ao Prof. Dr. Ivã Gurgel pela leitura crítica e indicações para a escrita deste artigo e, principalmente, pela orientação de minha tese de doutorado, contexto no qual surgiram as reflexões aqui apresentadas.

\section{Referências Bibliográficas}

ALLCHIN, D. Teaching the Nature of Science: perspectives and resources. SHiPS Education Press, 2013. 310 p.

BAGDONAS, A.; ZANETIC, J.; GURGEL, I. Controvérsias sobre a natureza da ciência como enfoque curricular para o ensino de física: o ensino de história da cosmologia por meio de um jogo didático. Revista Brasileira de História da Ciência, Rio de Janeiro, v. 7, n. 2, p. 242-260, dez. 2014. 
BERTOLLI, C. Elementos fundamentais para a prática do jornalismo científico. Disponível em: $\quad<$ http://www.bocc.ubi.pt/pag/bertolli-claudio-elementos-fundamentaisjornalismo-cientifico.pdf $>$. Acesso em: 10 jun. 2020.

BÉVORT, E.; BELLONI, M. Mídia-educação: conceitos, história e perspectivas. Educação \& Sociedade, Campinas, v. 30, n. 109, p. 1081-1102, dez. 2009.

BRASIL. Relatório Final da Pesquisa Brasileira de Mídia - 2016. Presidência da República/ Secretaria de Comunicação Social (SECOM). Empresa Responsável: IBOPE inteligência. Brasília - DF. 2016.

CALDAS, G. Mídia, escola e leitura crítica do mundo. Educação \& Sociedade, Campinas, v. 27, n. 94, p.117-130, abr. 2006.

CARDOSO, D.; GURGEL, I. Por uma educação científica que problematize a mídia. Linhas Críticas, Brasília, v. 25, p. 74-93, fev. 2019.

COSTA, B. et al. O movimento antivacina no YouTube nos tempos de pós-verdade: Educação em saúde ou desinformação? Revista Mídia e Cotidiano, Niterói, v. 14, n. 1, p. 220-239, abr. 2020.

FREIRE, P.; GUIMARÃES, S. Educar com a mídia: novos diálogos sobre educação. São Paulo: Paz e Terra, 2011. 238p.

GENESINI, S. A pós-verdade é uma notícia falsa. Revista USP, São Paulo, n. 116, p. 45-58, mar. 2018.

JANDRIÉ, P. Post-truth and critical pedagogy of trust. In: PETERS, M.; HYVONEN, M.; BESLEY (Ed.) Post-truth, Fake news: viral modernity \& higher education. Singapore: Springer, 2018. cap. 8, p. 101-112.

LAZER, D. et al. The Science of Fake News. Science. Policy Forum, v. 359, n. 3680, p. 1094-1096, mar. 2018.

LEITE, L. MATOS, J. Zumbificação da informação: A desinformação e o caos informacional. Revista Brasileira de Biblioteconomia e Documentação, São Paulo, v. 27, n. esp. CBBD, p. 2334-2349, out. 2017.

MARTINS, A. F. Natureza da ciência no ensino de ciências: uma proposta baseada em "temas" e "questões". Caderno Brasileiro de Ensino de Física, Florianópolis, v. 32, n. 3, p. 
703-737, dez. 2015.

MEDITSCH, E.; FARACO, M. O pensamento de Paulo Freire sobre Jornalismo e Mídia. Revista Brasileira de Ciências da Comunicação, São Paulo, v. 26, n. 1, p. 25-46, jun. 2003.

MORAES, R. Uma tempestade de luz: a compreensão possibilitada pela análise textual discursiva. Ciência \& Educação, Bauru, v. 9, n. 2, p. 191-210, jun. 2003.

MORAES, R; GALIAZZI, M. Análise textual discursiva: processo reconstrutivo de múltiplas facetas. Ciência \& Educação: Bauru, v.12, n. 1, p. 117-128, jan. 2006.

PEZZO, M. Olhares de Professores de Ciências em Formação sobre as Mídias, sua Inserção no Ensino e a Educação para as Mídias. 2016. 202 f. Tese (Doutorado em Educação) - Centro de Educação e Ciências Humanas, Universidade Federal de São Carlos, São Carlos.

PRAZERES, M. Educação não escolar de adultos e comunicação: um estado da arte 1999 a 2006. Revista e-curriculum, São Paulo, v. 5, n.1, dez. 2009.

RIBEIRO, R.; KAWAMURA, M. R. Ensino de Física e formação do espírito crítico: reflexões sobre o papel da divulgação científica. In: ENCONTRO DE PESQUISA EM ENSINO DE FÍSICA, XI, 2008, Curitiba, PR. Atas... Curitiba: Sociedade Brasileira de Física, 2008. p. 1-13.

TEIXEIRA, M. Pressupostos do jornalismo de ciência no Brasil. In: MASSARANI, L., MOREIRA, I.; BRITO, F (Ed.). Ciência e Público: caminhos da divulgação científica no Brasil. Rio de Janeiro: Editora UFRJ, 2002. cap.10, p.133-142.

ZAMBONI, L. Cientistas, jornalistas e a divulgação científica: subjetividade e heterogeneidade no discurso da divulgação científica. São Paulo: Autores Associados, 2001. $167 \mathrm{p}$.

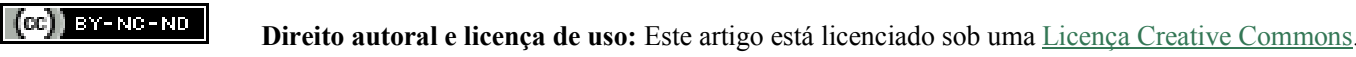

